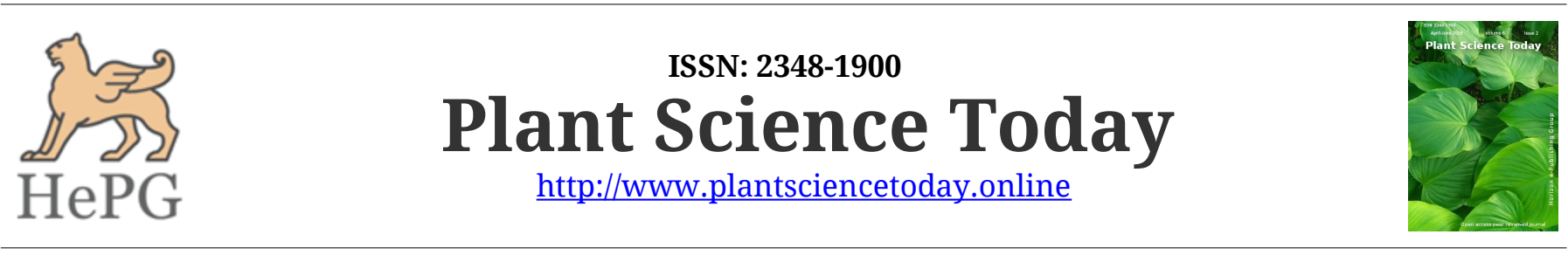

OPEN ACCESS

Review Article

\title{
Review on the genus Tectaria Cav. from India
}

\author{
Sachin M Patil", Ronak N Kachhiyapatel \& Kishore S Rajput \\ Department of Botany, Faculty of Science, The M. S. University of Baroda, Vadoadara 390002, India
}

\section{Article history}

Received: 20 February 2019

Accepted: 04 April 2019

Published: 27 April 2019

\section{Publisher}

Horizon e-Publishing Group

\author{
${ }^{*}$ Correspondence \\ Sachin M. Patil \\ $\square_{\text {sach2010d@gmail.com }}$
}

\begin{abstract}
The fern genus Tectaria Cav. (Tectariaceae) is one of the largest, morphologically diverse and more complex genera having difficulties in identifying the species and their groups. Since its description, a number of new genera had been separated from it or merged within it created considerable ambiguity. Thus, the main aim of the present review is to provide comprehensive information of the taxonomy, cytology, anatomy, palynology and molecular research carried out so far on the genus Tectaria. Present work is not merely compilation but includes personal observations and is presented here after critical evaluation.
\end{abstract}

Keywords: Fern; diversity; cytology; taxonomy; Tectariaceae

Citation: Patil SM, Kachhiyapatel RN, Rajput KS. Review on the genus Tectaria Cav. from India. Plant Science Today 2019;6(2):170-182. https://doi.org/10.14719/pst.2019.6.2.511

Copyright: (C) Patil et al (2019). This is an open-access article distributed under the terms of the Creative Commons Attribution License, which permits unrestricted use, distribution, and reproduction in any medium, provided the original author and source are credited (https://creativecommons.org/licenses/by/4.0/).

Indexing: Plant Science Today is covered by Scopus, CAS, AGRIS, CABI, Google Scholar, etc. Full list at http://www.plantsciencetoday.online

\section{Introduction}

As an important group of ferns, different species of Tectaria are known to occupy a variety of ecological niches across different habitats in numerous forest ecosystems of the country. The diversity, conservation status and state of knowledge of Tectaria (Tectariaceae) are not uniform worldwide. The genus Tectaria Cav., is popularly known as "halberd fern", was described by Cavanilles (1). The genus is mostly distributed in tropical regions and maximum species are terrestrial in rain forests (2). The word Tectaria was derived from Latin words "tectum" means "a covering" and the "adjectival suffic-aria", referring to the "indusium" (118). Generally, Tectaria species are small to large sized herbs, having erect, suberect or creeping rhizome, monomorphic or dimorphic, unipennate, bipinnatetetrapinnate fronds, growing along the roadsides, edges of hills and hillocks, along the water channels from low to high altitude or in different forests types (semi-arid to evergreen forests) (48). Due to its remarkable diverse morphology, there is no unanimous opinion on the number of species in this genus. According to Tryon and Tryon (3) and Kramer (4) there are nearly 150 species, while Holttum (5) and Ding et al. (2) considered about 230 species throughout the globe. However, according to PPG-I (6) there are ca. 200 species are accepted internationally.

Thus, the present review intends to compile various studies on this fern from worldwide and critically evaluates the issues related to the taxonomy, anatomy, cytology, palynology and molecular research on this genus.

\section{Taxonomic history}

The treatment of tectaroid ferns has unorthodoxically undergone several changes in their names time to time. It was popularly known as 
Aspidium Sw., whereas few species were treated under the Dryopteris Adans., Nephrodium Marthe ex Michx., Pleocnemia C. Presl., and Polystichum Roth. The genus Tectaria was described by Cavanilles (1). Soon after discovery of Tectaria, describe a new genera Aspidium by Swartz (7) for the same and this name was widely accepted by several pteridologists. Later on, many new genera, viz., Arcypteris Underw., Pleocnemia C. Presl, and Sagenia C. Presl, were described and accepted by many pteridologists (8-10). Beddome (11-12) reported different tectaroid ferns, viz., Aspidium and Plecomenia, although these generic delimitations were widely adopted at that time by pteridologists; it was ultimately recognized as illegitimate names. However, the concept of Tectaria was progressively accepted by pteridologists in the $20^{\text {th }}$ century.

The first major work on tectaroid ferns in the $20^{\text {th }}$ century was Christensen's "Index Filicum" (13). Further, he realised that the species listed under the genus Dryopteris were an unnatural mixture which indeed needs further study. First time he pointed out the presence of ctenitoid type of hairs in the species aggregate under the genus Dryopteris. He distinguished Ctenitis from Dryopteris, pointing out the relationship of the former to Tectaria and also has anastomosing veins in thelypteroid ferns. At the same time, Copland (14) studied the Philippine species and recognized seven groups, viz., the Arcypteris group, the Cicutariae group, the Crenatae group, the Decurrentes group, the Pleocnemia group, the Trifoliatae-Polymorphae group, and the Vastae group. Subsequently, Christensen (15) made an effort to differentiate natural assemblies within that mixture by exploring the species of tropical America. Later on, he published a monograph "Index Filicum" (16), subgenera, though he observed them as very diverse and specified that some should eventually have generic rank. Blater and d'Almeida (17) studied the ferns of Bombay presidency and reported 06 species of Aspidium. Ching (18) for the treatment of Tectaria from China and Sikkim-Himalaya, divided the genus into three sections, viz., T. sect. Arcypteris (Underw.) C. Chr., T. sect. Pleocnemia (C. Presl) Diels, and T. sect. Eutectaria Ching $(=T$. sect. Tectaria). Christensen (19) published the classification of extant ferns retained a major family Polypodiaceae with two subfamilies, one is Dryopteridoideae which includes the genus Dryopteris and second is Thelypteridaceae which includes the genus Tectaria with other related genera. Later on, Ching (20) divided Christensen's Polypodiaceae into several families, amongst these Aspidiaceae is one which is similar to Christensen's subfamily Dryopteridoideae. This family Aspidiaceae is divided into tribes, Aspidieae (includes Tectaria and its allies) and Dryopterideae (includes Dryopteris and related genera). Ching (20) also accepted the genera, viz., Arcypteris Underw., Pleocnemia C. Presl, and Sagenia C. Presl. Holttum
(21) raised these tribe to subfamily rank but placed under the family Dennstaedtiaceae. For separating these subfamilies, different characters, viz., costae, smaller rachises grooved, and groove with raised edges for the Dryopteridoideae and costae raised, not grooved, presence of hairs for the Aspidieae were used. He accepted many new genera, viz., Amphiblestra C.Presl, Arcypteris Underw., Ctenitis (C. Chr.) C. Chr., Cyclopeltis J. Sm., Dictyoxiphium Hook., Hemigramma Christ, Heterogonium C.Presl, Lastreopsis Ching, Pleocnemia C. Presl, Pleuroderris Maxon, Pteridrys C. Chr. \& Ching, Quercifilix Copel., Stenosemia C. Presl and Tectaria Cav., in his classification system. At the same time Copland (22) recognized a large family Aspidiaceae, including the genera, viz., Thelypteris and its allies, Athyrium, Diplazium and Lomariopsis. Subsequently, Holttum (23) Arcypteris Underw., is maintained as different from Tectaria and is very closely related to Pleocnemia rather than Tectaria. Pichi Sermolli (24) had proposed to conserve the family Aspidiaceae but it failed because the family name Aspidiaceae is illegitimate since it is based on an illegitimate generic name Aspidium. Nayar (25) didn't follow the Ching's classification and placed tectarioid and Dryopteris group of ferns in separate subfamilies of Dryopteridaceae. Mathew (26) studied diversity of pteridophytes of Darjeeling district and reported Tectaria cicutaria and T. polymorpha from Darjeeling. Sledge (27) studied the tectarioid ferns of Ceylon and reported five genera (Hypodematium, Ctenitis, Lastreopsis, Tectaria and Pteridrys) and sixteen species with the rejection of the genus Quercifilix. In disparity, a number of unlike genera had been isolated from Tectaria, viz., Aenigmopteris Holttum, Amphiblestra, Aspidium, Camptodium, Cardiochlaena Fée, Chlamydogramme Holttum, Cionidium T. Moore, Ctenitopsis Ching ex Tardieu \& C. Chr., Dictyoxiphium, Dictyopteris J.V. Lamour., Dryomensis Fée, Fadyenia, Hemigramma, Heterogonium, Luerssenia Kuhn ex Luerssen, Microbrochis C. Presl, Phlebiogonium Fée, Pleocnemia, Pleuroderris, Podopeltis Fée, Psomiocarpa C. Presl, Pseudotectaria Tardieu-Blot, Quercifilix, Sagenia, Stenosemia, and Trichiocarpa (Hook.) J. Sm., by various pteridologists (28). In addition, some species of Ctenitis and Dryopteris Adans., are often treated as members of Tectaria which has on occasion led to unstable delimitations of those genera $(3,29)$. Holttum (30) studied the genus Tectaria from Mascarene Islands. On the basis of venation patterns, he divided the genus Tectaria of Mascarene Islands into three groups i.e. Group I includes the species ( $T$. picta and $T$. puberula) having elaborate network of veins, with free veinlets, often branched, which run in all direction in the areoles of the network including the areole of the main veins of the pinnae. Group II includes the species (T. gemmifera) had no free veinlets in the areoles of the costae and costules, few outwardly directed 
unbranched veinlets however present in other areoles and Group III includes the species ( $T$. fuscipes) having free veins with or without areoles along the costa. Dixit (31) published a censes on Indian Pteridophytes and considered ten genera, viz., Acrorumohra, Ctenitis, Ctenitopsis, Cyrtomium, Didymochlacna, Lastreopsis, Pleocnemia, Pteridrys, Quercifilix, Tectaria etc., in the family Aspidiaceae. Holttum (32) had carried out survey on tectaroid ferns of Asia, Malesia and Western Pasific and proposed seventeen new species of the genus Ctenitis, one new generic name and made four new combinations of this genus. Also, discussed difference between Ctenitis and Tectaria. The genus Ctenitis has free veins, differing from the Holttum's third group of Tectaria in the position of origin of the basal basiscopic vein in each pinnalobe. Ctenitis also differs from Tectaria in the presence of scales on all the axes of the frond and in the thin, clathrate structure of the smaller scales. In Tectaria the scales are usually confined to the stipe and are never clathrate. Panigrahi (33) had proposed a new family Tectariaceae (rejecting the family Aspidiaceae) and it was accepted by subsequent researchers. It includes 17 genera and 527-538 species including Tectaria and some other closely related genera. Pande (34) studied the ferns of Kumaon Hills and recorded two species of Tectaria, viz., T. coadunata and T. dubia. Holttum (35) described some new taxa in Tectaria group from Malesia and new combinations of Tectaria were also made. Khullar (36) documented the members of Tectaria, Dryopsis and Ctenitis of Tectariaceae found in the West Himalayas. A broad-leaf variant of fern rheophyte, Tectaria lobbi is reported from Borneo (37). They concluded that broad-leaved forms are developed from the narrow-leafleted one, which took place during the course of evolution of Rheophytes from dryland species, although the direction of changes was opposite in the two cases. Manickam and Irudayaraj (38), Irudayaraj \& Bir (39) and Rajagopal \& Bhat (40) reported different species of Tectaria, viz., T. coadunata, $T$. paradoxa, $T$. polymorpha and T. wightii from Western Ghats. During the floristic survey of pteridophytes from Tawau Hills, Sabah, Bidin \& Jaman (41) reported three species of tectaroid ferns, viz., Pleocnemia conjugata, Tectaria angulata and $T$. singaporeana. At the same time Jaman, et al. (42) surveyed the pteridophytes of Bario, Keiabit Highlands and reported Ctenitis aciculate, Pleocnemia hemiteliiformis and five species of Tectaria. Chandra (43) in his "Ferns of India" listed six genera of tectaroid ferns, viz., Tectaria (22), Pleocnemia (1), Pteridrys (2), Lastreopsis (1), Dryopsis (6) and Ctenitis (3) under the subfamily Tectarioideae. Rojas (44) studied the tectaroid ferns from Nicaragua, Costa Rica, Panama, Colombia and Peru and described many new species, viz., Ctenitis sotoana A. Rojas, Megalastrum ctenitoides A. Rojas, Tectaria darienensis A. Rojas, T. faberiana A. Rojas, T. longipinnata A. Rojas, T. murilloana A. Rojas, T. pascoensis A. Rojas and T. subdimorpha A. Rojas along with a new combination of Megalastrum karstenianum (Klotzsch) A. Rojas. Tectaria polymorpha is reported from Hainan Island, China (45). They merged the variety $T$. polymorpha var. subcuneata under $T$. polymorpha and also discussed the morphological variation of $T$. subtriphylla and differences between $T$. simonsii and T. media. Smith (46) described two new species of Tectaria, viz., T. atropurpuria and $T$ microsora from the Rio Cenepa Area, Amazonas and Peru. Fraser-Jenkins (47) published a "Taxonomic Revision of Indian Subcontinental Pteridophytes" and listed 01 species of Ctenitis, 06 species of Dryopsis, 01 species of Heterogonium, 01 species of Lastreopsis, 01 species of Pleocnemia, 03 species of Pteridrys and 22 species of Tectaria. Patil et al. (48) studied the Tectaria from Northern Western Ghats and reported 04 species from which $T$. fuscipes was added as new distributional record for Western Ghats of India. Antony et al. (49) reported an African element, Tectaria puberula as a new distributional record for India. Recently, Dong (50) is corrected the misapplication of the name Tectaria subsageniacea (Tectariaceae) in China. Similarly, A new species of Tectaria, Tectaria moranii (Tectariaceae), from Costa Rica is described (51). Also, Fraser-Jenkins et al. (52) published a book on Indian pteridophytes " $A n$ Annotated checklist of Indian Pteridophytes Part 2" and retained 24 species of Tectaria. After reviewing the literature, it was observed that genus Tectaria having more complexity hence many new genera separated from the genus world-wide while some of them were merged. However, in India since last 2-3 decades very much confusions were created on the occurrence of species as well as in identification of earlier pteridologists. Hence there is an urgent need to study the taxonomy of the genus Tectaria from which helps to solve the taxonomic complex in India.

\section{Taxonomy}

Tectaria is terrestrial, medium to large size herb, growing along the cut edges of hills and hillocks or edges of river, having erect ( $T$. ingens and $T$. paradoxa), suberect (T. chattagrammica, $T$. fuscipes and $T$. trimenii) short creeping ( $T$. polymorpha and $T$. simonsii) or long creeping rhizome (T. coadunata, T. impressa, T. wightii and T. herpetocaulos) (Fig. 1 a-d); fronds either monomorphic (T. coadunata), dimorphic ( $T$. fuscipes, T. heterocarpa, T. polymorpha, T. wightii and T. zeilanica) or subdimorphic (T. paradoxa); lamina decurrens ( $T$. decurrens and $T$. vasta), simple pinnate with or without lower pinnae lobe ( $T$. heterocarpa, T. polymorpha, T. wightii and T. pseudosiifolia), bipinnate-tripinnate (T. chattagrammica, T. coadunata, T. fuscipes, 


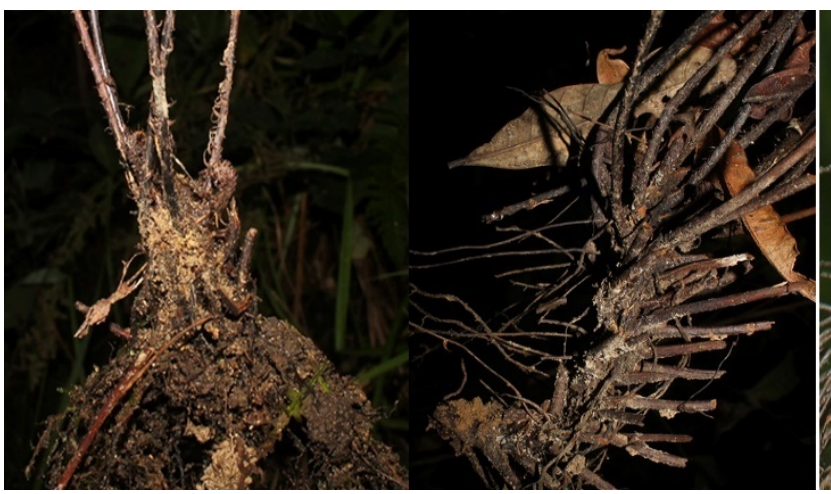

a. Erect rhizome

b. suberect

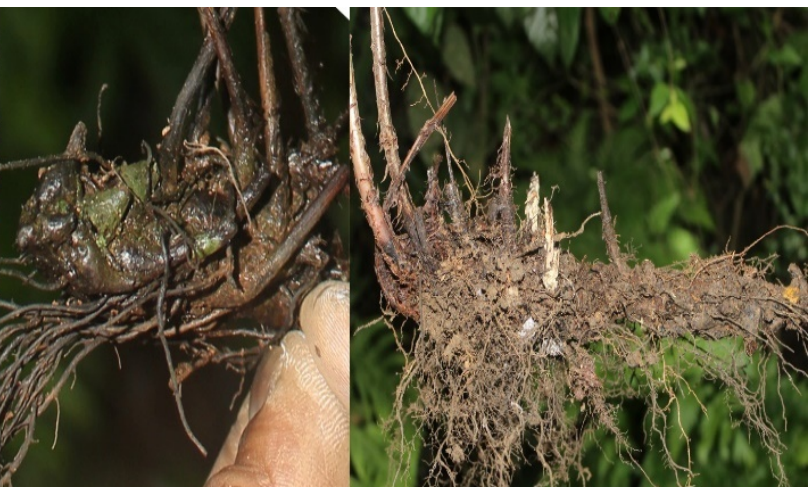

c. short-creeping

d. long-creeping

Fig. 1 (a-d): Different type of rhizome in the genus Tectaria

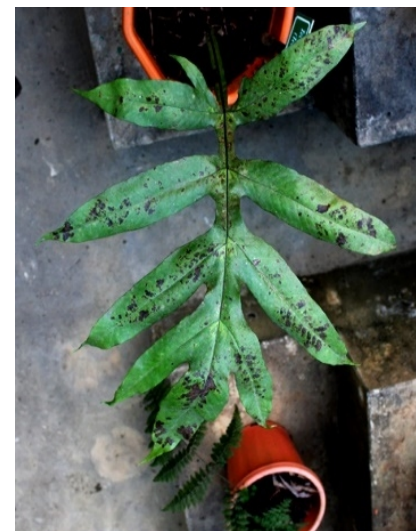

e. decurrens frond

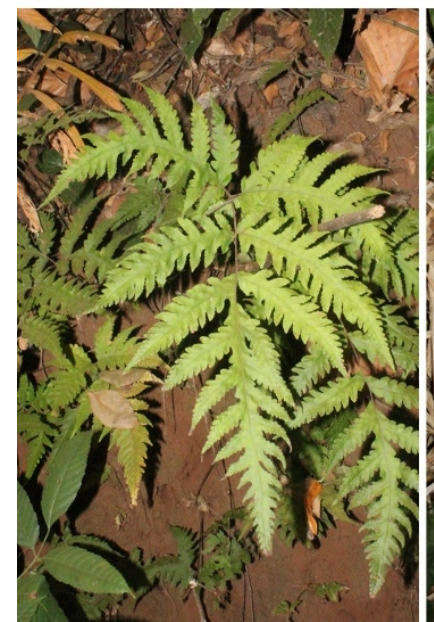

i. bipinnate-pinnatisect

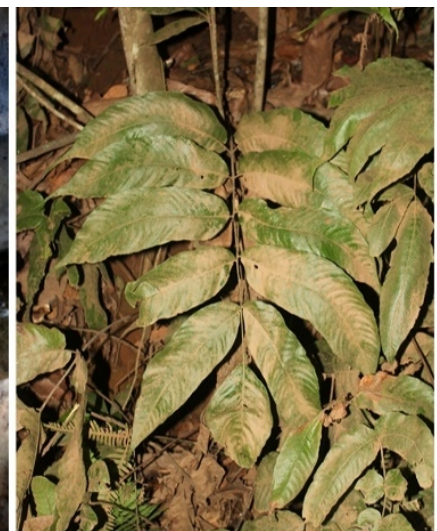

f. simple pinnate

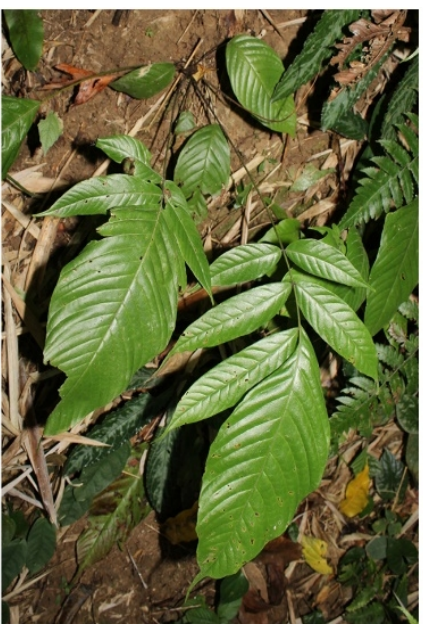

j. heterocarpa type

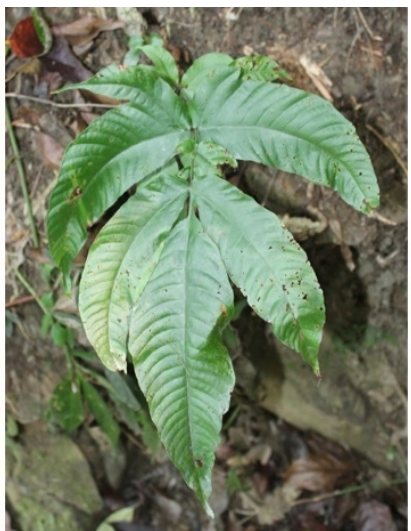

g. simple pinnate with lob

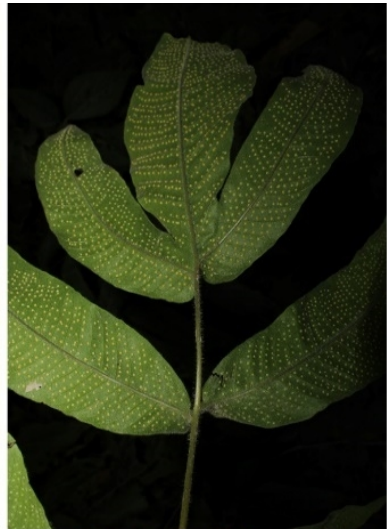

h. densely hairy frond

Fig. 1 (e-1): Different type of types of pinnae in the genus Tectaria

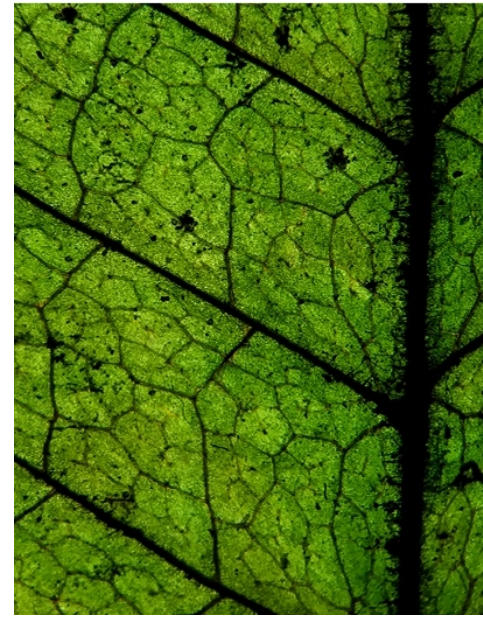

m. polymorpha type

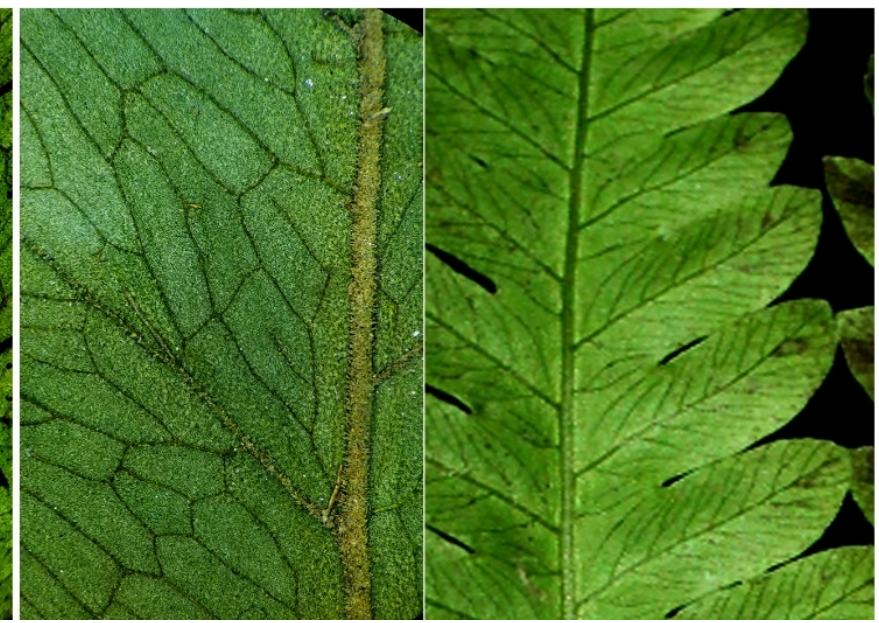

n. coadunata type

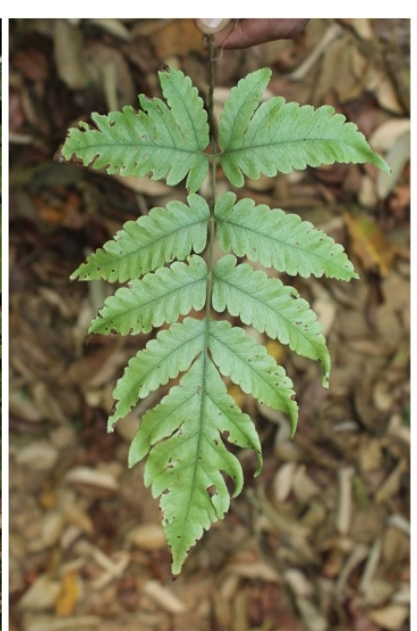

k. bi-pinnatifid

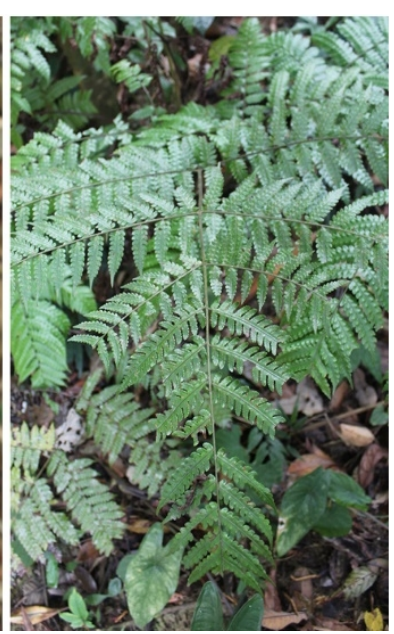

1. tri-tetrapinnate

Fig. 1 (m-p): Different type of types of venation pattern in the genus Tectaria

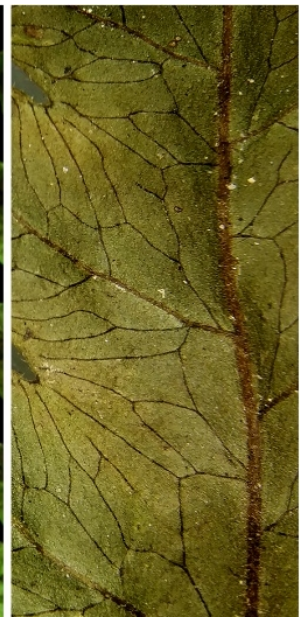

p. fuscipes type 
T. gemmifera, T. impressa, T. paradoxa and $T$. puberula) or > tripinnate (T. ingens) (Fig. 1 e-l); lamina densely hairy on both side ( $T$. coadunata, T. puberula and T. multicaudata), lamina hairy on lower side only (T. pseudosiifolia), lamina sparsely scaly both side ( $T$. fuscipes and T. impressa), lamina glabrous ( $T$. griffithii, $T$. heterocarpa, $T$. wightii and T. vasta); veins visible on lower side, they are polymorpha type i.e. anastomosing with branched included veinlets ( $T$. polymorpha, $T$. heterocarpa, T. pseudosiifolia and T. wightii); coadunata type i.e. anastomosing without branched veinlets (T. coadunata, $T$. chattagrammica, T. gemmifera, T. griffithii, $T$. multicaudata and $T$. puberula) paradoxa types veins i.e. free veins (T. paradoxa and T. ingens) and fuscipes type i.e. free but areole along the costa and costule (T. fuscipes and T. trimenii) (Fig. $1 \mathrm{~m}-\mathrm{p}$ ); sori many, indusiate ( $T$. coadunata, $T$. fuscipes, $T$. ingens, T. paradoxa,), exinduciate (T. wightii); indusia either persistent (T. paradoxa) or shaded (T. polymorpha); spores monolete or trilete. The treatment of tectaroid ferns has un-orthodoxically undergone several changes in their names time to time.

In India, about 35 species were reported by earlier workers $(31,38,53,48)$ of which 24 species were accepted by Fraser-Jenkins et al. (52) (Table 1). On the basis of type of fronds, venation pattern, all the collected Tectaria species were categorised into 3-groups, viz., Group I - polymorpha complex, Group II - coadunata complex, and Group III paradoxa complex (Table 2).

The Group I - polymorpha complex includes the species which are having subdimorphicdimorphic, simple pinnate, lobed or unlobed fronds, veins anastomosing forming areoles with branched veinlets. The species, viz., Tectaria decurrens, T. fauriei, $T$. herpetocaulos, $T$. heterocarpa, T. kehdingiana, T. melanocaulos $T$. polymorpha, T. pseudosiifolia, T. simonsii, $T$. wightii and T. vasta are included in the Group I. The coadunata complex includes the species which are having monomorpic-subdimorphic or dimorphic, adnate, bipinnate to tetrapinnate fronds, vein anastomosing with included veinlets. The species, viz., Tectaria chattagrammica, $T$. coadunata, T. gemmifera, T. griffithii, T. impressa, T. multicaudata T. puberula, T. subconfluens and T. zeilanica. are included in the Group II. The paradoxa complex includes the species which are having subdimorphic-dimorphic, bipinnate to bipinnatified fronds, veins free, with or without areoles at along the costa or costule and without included veinlets. The species, viz., Tectaria fuscipes, Tectaria ingens, T. paradoxa and $T$. trimenii are included in the Group III.

\section{Diversity and distribution in India}

On the basis of climate and ecology, India is divided into 10 biogeographic regions, viz., Trans
Himalaya (cold), Himalaya's (cold-moderate), North-East (cold-moderate), Gangatic plain (moderate-warm), Desert (hot), Semi-Arid (moderate-hot), Deccan Peninsula (moderatewarm), Western Ghats (cold-moderate), Indian Coasts (humid-warm), Andaman and Nicobar Islands (humid-warm). A sum total of 24 species were reported from India by Fraser-Jenkins et al. (2018). All these species were distributed in different bio-geographic regions of India (Table 1). They are either growing along the river, stream, water fall, or along the roadside, hilly slopes and cut edges. All the species were collected in between $200-1800 \mathrm{~m}$. The majority of species (14 species) were found in Eastern Himalaya's (Tectaria chattagrammica, T. coadunata, T. decurrens, T. fauriei, T. fuscipes, T. griffithii, T. heterocarpa, $T$. ingens, $T$. multicaudata, T. polymorpha, T. pseudosiifolia, T. simonsii, $T$. subconfluens and T. vasta) followed by North-East region nestle 13 species ( $T$. chattagrammica, $T$. coadunata, T. decurrens, $T$. fauriei, T. fuscipes, $T$. griffithii, T. heterocarpa, T. impressa, T. ingens, T. polymorpha, T. simonsii, T. subconfluens and $T$. vasta), Western Ghats having 09 species ( $T$. coadunata, T. fuscipes, T. gemmifera, T. paradoxa, T. polymorpha, T. puberula, T. trimenii, T. wightii, and T. zeilanica) and Gangetic plains having 09 species (Tectaria chattagrammica, T. coadunata, $T$. decurrens, T. fauriei, T. fuscipes, T. heterocarpa, T. impressa, T. polymorpha and T. simonsii) whereas 1-5 species were collected from other biogeographic zones. However, none of the species were collected or reported from Desert. The most common species are Tectaria coadunata, $T$. fuscipes and T. polymorpha whereas other species are restricted to 1-3 biogeographic zones (Fig. 2). The species, viz., T. paradoxa, $T$. wightii and $T$. trimenii are endemic to the Western Ghats and Sri Lanka. However, the species, viz., $T$. chattagrammica, T. fauriei, $T$. griffithii, $T$. heterocarpa, T. ingens, $T$. pseudosiifolia, $T$. simonsii, T. subconfluens and T. vasta are restricted to either Eastern Himalaya's or North-East India, whereas the species, viz., T. paradoxa T. puberula, T. wightii and T. zeilanica are restricted to Western Ghats and the species, viz., T. herpetocaulos, T. kehdingiana and T. melanocaulos are restricted to Andaman and Nicobar Islands.

\section{Anatomical studies}

Though, anatomical studies on vascular cryptogams are carried out time to time by different pteridologists, anatomy of this group is relatively unexplored. The most primitive type of stele i.e. protostele is reported in Filicineae, and subsequently solenostelic and dictyostelic vascular systems gradually evolved from this primitive type of stele in rhizome (55). Rhizome, stipe and rachis of all tectarioid ferns possess dictyostelic vascular systems whereas in roots stele shows presence of protostele. Copeland (22) investigated anatomy 
Table 1: Tectaria species with account on their identity, diversity and distribution studies from India

\begin{tabular}{|c|c|c|c|}
\hline Species & Identity in India & Distribution & Reported by \\
\hline $\begin{array}{l}\text { Tectaria brachiata (Zoll. \& } \\
\text { Moritzi) C.V.Morton }\end{array}$ & Error for T. impressa & - & Fraser-Jenkins, (47) \\
\hline $\begin{array}{l}\text { T. chattagrammica } \\
\text { (C.B.Clarke) Ching }\end{array}$ & Identity confirmed & $\begin{array}{c}\text { Arunachal Pradesh, Assam, } \\
\text { Manipur, Meghalaya, Mizoram and } \\
\text { Tripura }\end{array}$ & Fraser-Jenkins et al., (52) \\
\hline T. cicutaria (L.) Copel. & Error for T. coadunata & - & Fraser-Jenkins (47) \\
\hline $\begin{array}{l}\text { T. coadunata (Wall. ex } \\
\text { Hook. \& Grev.) C. Chr. }\end{array}$ & Identity confirmed & Throughout India & $\begin{array}{l}\text { Manickam and Irudayaraj (38); } \\
\text { Singh \& Panigrahi 53; Patil et al. } \\
\text { (48); Fraser-Jenkins et al. (47) }\end{array}$ \\
\hline T. decurrens (C.Presl) Copel. & Identity confirmed & $\begin{array}{l}\text { Arunachal Pradesh, Assam, } \\
\text { Manipur, Meghalaya, Mizoram, } \\
\text { Tamil Nadu and Tripura }\end{array}$ & $\begin{array}{l}\text { Singh \& Panigrahi (53); Fraser- } \\
\text { Jenkins et al. (47) }\end{array}$ \\
\hline $\begin{array}{l}\text { T. dubia (C.B.Clarke \& } \\
\text { Baker) Ching } \\
\end{array}$ & Syn. of T. griffithii & - & Fraser-Jenkins (47) \\
\hline T. fauriei Tagawa & Identity confirmed & $\begin{array}{c}\text { Arunachal Pradesh, Assam State, } \\
\text { Meghalaya }\end{array}$ & Fraser-Jenkins et al. (52) \\
\hline $\begin{array}{l}\text { T. fuscipes (Wall. ex Bedd.) } \\
\text { C.Chr }\end{array}$ & Identity confirmed & $\begin{array}{l}\text { Arunachal Pradesh, Assam, } \\
\text { Karnataka, Manipur, Mizoram, } \\
\text { Meghalaya, Nagaland, Sikkim, } \\
\text { Tripura and West Bengal } \\
\end{array}$ & $\begin{array}{l}\text { Singh \& Panigrahi (53); Patil et al. } \\
\text { (48); Fraser-Jenkins et al. (52) }\end{array}$ \\
\hline T. gemmifera (Fee) Alston & Identity confirmed & Kerala, Tamil Nadu & Fraser-Jenkins et al. (52) \\
\hline T. gigantea (Blume) Copel. & $\begin{array}{l}\text { Syn. of Heterogonium } \\
\text { giganteum }\end{array}$ & North-East India & Fraser-Jenkins (47) \\
\hline T. griffithii (Baker) C. Chr. & Identity confirmed & $\begin{array}{l}\text { Arunachal Pradesh, Assam, } \\
\text { Meghalaya }\end{array}$ & $\begin{array}{c}\text { Singh \& Panigrahi (53); Fraser- } \\
\text { Jenkins et al. (52) }\end{array}$ \\
\hline T. herpetocaulos Holttum & Identity confirmed & Andaman \& Nicobar Islands, & Fraser-Jenkins et al. (52) \\
\hline $\begin{array}{l}\text { T. heterocarpa (Baker) } \\
\text { Ching, }\end{array}$ & Identity confirmed & $\begin{array}{l}\text { Arunachal Pradesh, Assam, } \\
\text { Manipur, Meghalaya, Mizoram, } \\
\text { Nagaland, Tripura, West Bengal }\end{array}$ & $\begin{array}{l}\text { Singh \& Panigrahi (53); Fraser- } \\
\text { Jenkins et al. (52) }\end{array}$ \\
\hline T. impressa (Fee) Holtum & Identity confirmed & $\begin{array}{c}\text { Arunachal Pradesh, Assam, } \\
\text { Manipur, Meghalaya, Mizoram, } \\
\text { Nagaland, } \\
\text { Tripura, West Bengal } \\
\end{array}$ & Fraser-Jenkins et al. (52) \\
\hline T. ingens (Desv.) C.Chr. & Identity confirmed & $\begin{array}{l}\text { Arunachal Pradesh, Manipur, } \\
\text { Meghalaya, Mizoram, Nagaland }\end{array}$ & Fraser-Jenkins et al. (52) \\
\hline $\begin{array}{c}\text { T. khonsaensis Sarn.Singh \& } \\
\text { Panigrahi } \\
\end{array}$ & Syn. of T. polymorpha & North-East India & Fraser-Jenkins et al. (52) \\
\hline $\begin{array}{c}\text { T. kehdingiana (Kuhn) M.G. } \\
\text { Price }\end{array}$ & Identity confirmed & Andaman \& Nicobar Island & Fraser-Jenkins et al. (52) \\
\hline $\begin{array}{l}\text { T. macrocarpa (Bedd.) } \\
\text { B.K.Nayar \& Geev. }\end{array}$ & Syn. of T. wightii & - & Fraser-Jenkins et al. (52) \\
\hline T. macrodonta C. Chr. & Syn. of $T$. coadunata & - & Fraser-Jenkins et al. (52) \\
\hline $\begin{array}{l}\text { T. mehrae Panigrahi \& } \\
\text { Sarn.Singh }\end{array}$ & $\begin{array}{c}\text { Syn. of } \\
\text { T. multicaudata }\end{array}$ & - & Fraser-Jenkins et al. (52) \\
\hline $\begin{array}{l}\text { T. melanocaulos (Blume) } \\
\text { Copel. }\end{array}$ & Identity confirmed & Andaman \& Nicobar Island & Fraser-Jenkins et al. (52) \\
\hline $\begin{array}{l}\text { T. multicaudata (C.B. } \\
\text { Clarke) Ching }\end{array}$ & Identity confirmed & $\begin{array}{c}\text { Arunachal Pradesh, Assam, } \\
\text { Meghalaya, Sikkim }\end{array}$ & Fraser-Jenkins et al. (52) \\
\hline $\begin{array}{l}\text { T. pandurifola (C.Chr.) } \\
\text { C.Chr. }\end{array}$ & $\begin{array}{c}\text { Error for } \\
\text { T. heterocarpa }\end{array}$ & North-East India & Fraser-Jenkins et al. (52) \\
\hline T. paradoxa Sledge & Identity confirmed & $\begin{array}{c}\text { Andhra Pradesh, Karnataka, } \\
\text { Kerala, Tamil Nadu }\end{array}$ & $\begin{array}{l}\text { Patil et al. (48); Fraser-Jenkins et al. } \\
(52)\end{array}$ \\
\hline $\begin{array}{l}\text { T. polymorpha (Wall, ex } \\
\text { Hook.) Copel. } \\
\end{array}$ & Identity confirmed & Throughout India & $\begin{array}{l}\text { Singh and Panigrahi (53); Patil et al. } \\
\text { (48); Fraser-Jenkins et al. (52) }\end{array}$ \\
\hline $\begin{array}{l}\text { T. pseudosiifolia Fraser- } \\
\text { Jenkins \& Wangdi }\end{array}$ & Identity confirmed & Arunachal Pradesh & Fraser-Jenkins et al. (52) \\
\hline T. puberula C.Chr. & Identity confirmed & Kerala & $\begin{array}{c}\text { Antony et al. (49); Fraser-Jenkins et } \\
\text { al. (52) }\end{array}$ \\
\hline T. simonsii (Baker) Ching & Identity confirmed & $\begin{array}{c}\text { Assam, Meghalaya, Nagaland, and } \\
\text { Sikkim }\end{array}$ & Kholia (54); Fraser-Jenkins et al. (52) \\
\hline T. subconfluens Ching & Identity confirmed & $\begin{array}{c}\text { Arunachal Pradesh, Assam, } \\
\text { Meghalaya }\end{array}$ & $\begin{array}{c}\text { Singh and Panigrahi (53); Fraser- } \\
\text { Jenkins et al. (52) }\end{array}$ \\
\hline $\begin{array}{l}{ }^{*} \text { T. subtriphylla (Hook. \& } \\
\text { Arn.) Copel. }\end{array}$ & Identity confirmed & Tamil Nadu & Fraser-Jenkins et al. (52) \\
\hline T. trimenii C. Chr. & Identity confirmed & Kerala, Tamil Nadu & Fraser-Jenkins et al. (52) \\
\hline $\begin{array}{l}\text { T. variolosa (Wall. ex Hook.) } \\
\text { C. Chr. }\end{array}$ & Syn. of $T$. impressa & - & Fraser-Jenkins et al. (52) \\
\hline T. vasta (Blume) Copel. & Identity confirmed & $\begin{array}{l}\text { Andaman \& Nicobar Islands } \\
\text { (Nicobars), Arunachal Pradesh, } \\
\text { Assam, Manipur, Meghalaya, } \\
\text { Mizoram, Nagaland, Tripura }\end{array}$ & $\begin{array}{l}\text { Singh and Panigrahi (53); Fraser- } \\
\text { Jenkins et al. (52) }\end{array}$ \\
\hline htii (C. B. Clarke) Ching & Identified taxon & Karnataka, Kerala and Tamil Nadu & $\begin{array}{l}\text { Manickam and Irudayaraj (38); Patil } \\
\text { et al. (48); Fraser-Jenkins et al. (52) }\end{array}$ \\
\hline $\begin{array}{l}\text { T. zeilanica (Houttuyn) } \\
\text { Sledge } \\
\end{array}$ & Identified taxon & Kerala and Tamil Nadu & Fraser-Jenkins et al. (52) \\
\hline
\end{tabular}


of the young sporophytes of several species of family Aspidiaceae. Subsequently, Holttum (23) studied anatomy of Pleocnemia and observed that vascular strands in stipe are abundant than that of Tectaria. Pleocnemia shows a single ring of small accessory strands along with additional large strands on the adaxial side. Rao and Khare (56) studied the anatomy of Tectaria amplifolia and observed the external ring or sclerotic ring of endodermis, which is an important character of tectarioid ferns. White (57) investigated the ontogenetic changes in stellar patters in young sporophytes of seven species of Tectaria and documented significance variations in the pattern of stele, which may help to resolve taxonomic problems in the Aspidiaceae.

Chandra and Kaur (58) elucidated vascular organization in the rhizome of ten species of Tectaria and noticed reduction in number of vascular strands and sclerenchyma cells in some species of Tectaria. According to them reduction of vascular strands in stele is an advanced character whereas presence of sclerenchyma strand is a primitive feature. Studies on venation pattern of many tectarioid ferns was carried by Salgado (59) and concluded that free vein pattern is probably representing a primitive feature from which much complex ones are evolved. According to him, complex included veinlets is the next step in the evolution of venation. The order and regularity in the arrangement of veins in Pteridrys syrmatica is more advance pattern. On the basis of anatomy of $T$ grandifolia, Salgado and Valera (60) also determined that radially symmetrical dictyostele, orderly arrangement of venation, linear soral arrangements, monolete spores and perisporate condition of spores may be considered as advanced character. Mittal and Bir (61) studied anatomy of Ctenitis apiciflora and $C$. nidus from the members of the same family and observed large number of sclerotic nests in the ground tissue of both rhizome and petiole. Jadhav (62) investigated anatomy of some pteridophyte species which includes $T$. coadunata. Ding et al. (63) in studied phylogeny and character evolution of the fern genus Tectaria in the Old-World species and analysed the venation pattern. They proposed 4 types of venation pattern in Tectaria, viz., fully free (or occasionally connected), partly free (forming costal and costular areoles, with few additional areoles without included veinlets), partly anastomosing (forming costal and costular areoles, with many additional areoles, but areoles lack of included veinlets) and fully anastomosing with free veinlets in nearly all areoles. In the genus Tectaria type of stele is dictyostele (observed in the rhizome, stipe and rachis) and protostele (observed in roots). As far as anatomical studies are concerned, only few species are investigated world-wide. However, in India, anatomy of a single species i.e. T. coadunata is studied while similar information on rest of the 23 species is lacking (Table 3). Therefore, there is an urgent need to study the anatomy of Tectaria species from India.

\section{Cytological studies}

Chromosome numbers is one of the important diagnostic features of cyto-taxonomy and is extensively used for species identity including delimitation of the taxa but chromosome data for all the species are not available. In pteridology, cytological studies are not thoroughly conducted because of poorly established methodology and existence of polyploidy. However, the studies are upsurge after the publication by Manton (64) "Problems of Cytology and evolution in the Pteridophytes". The cytological studied from Indian subcontinents possess both diploid apogamous and triploid apogamous. The diploid apogamous is well distributed in Himalaya's (6568). The basic chromosome number of genus Lastreopsis is $\mathrm{n}=40$ (69), which is similar to the genus Ctenitis. The cytological studies were carried out on variations in the number of chromosomes on the basis of different taxonomic groups, regions with different climate, geology, other environmental and historical factors (70-71). Evolution in many ferns involves changes in ploidy level and reproductive system. Ploidy and reproductive system are also involved in the biogeography of ferns $(72,73,74)$. Cytology of family Aspidiaceae from South India was carried out by Bhavnandan (75) and reported chromosome number of Tectaria is $2 n=40,2 n=80$ and $2 n=200$. Khare (76) published a note on the chromosome number of the fern flora of Amarkantak Hills, Central India. Cytology of different Tectaria species was carried out (3) and stated that mostly Tectaria having diploids with $\mathrm{n}=40$ or tetraploids with $\mathrm{n}=80$. Khare and Kaur (77) reported a new cytotypes of Pteris vittata from Lucknow (Uttar Pradesh, India). Irudayaraj \& Manickam (78) studied the cytology of some pteridophytes of Western Ghats and reported basic chromosome number $\mathrm{n}=41$ for $T$. paradoxa and $T$. wightii. Cytotaxonomic study of ferns from Yunnan (China) was studied (79) and reported the chromosome number of $T$. fuscipes $(\mathrm{n}=80)$. Karyomorphological studies on three Indian species of Tectaria, viz., Tectaria fuscipes, $T$. macrodonta and T. polymorpha have studied (80) and reported that all the three species are diploids and the basic chromosome number is $n=40$. Irudayaraj et al. (81) studied the intraspecific variation in South India ferns and rediscovery of the rare diploid cytotype of Christella parasitica (Thelypteridaceae: Pteridophyte). Bir and Varma (82) published a chromosome atlas of the Indian pteridophytes (included many Tecteria species). According to them cytological data played a significant role in the identity and phylogenetic affinities of several species and genera of ferns (82). Zhao and Dang (83) described a new hybrid of Tectaria (Tectariaceae) from Southern China. 
Table 2: Groups of Tectaria based on morphological characters

Polymorpha complex Tectaria decurrens, T. fauriei, T. herpetocaulos, T. heterocarpa, T. kehdingiana, T. melanocaulos T. polymorpha, T. pseudosiifolia, T. simonsii, T. wightii and T. vasta.

Coadunata complex Tectaria chattagrammica, T. coadunata, T. gemmifera, T. griffithii, T. impressa, T. multicaudata T. puberula, T. subconfluens and T. zeilanica.

Paradoxa complex Tectaria fuscipes, T. ingens, T. paradoxa and T. trimenii.

Table 3: Tectaria species with account on anatomy, cytology and palynology from India

\begin{tabular}{|c|c|c|c|}
\hline Species & Anatomical Studies & Chromosome Data & Palynology \\
\hline T. chattagrammica (C.B.Clarke) Ching & Not yet studied & Not yet studied & Not yet studied \\
\hline $\begin{array}{l}\text { T. coadunata (Wall. ex Hook. \& Grev.) } \\
\text { C. Chr. }\end{array}$ & Studied (11) & $n=40 \& 41$ & Studied (87) \\
\hline T. decurrens (C.Presl) Copel. & Not yet studied & $n=40 \mathrm{II}$ & Not yet studied \\
\hline T. fauriei Tagawa & Not yet studied & $n=40 \mathrm{III}$ & Not yet studied \\
\hline T. fuscipes (Wall. ex Bedd.) C.Chr & Not yet studied & $n=40 ; 2 n=80(88)$ & Studied (87) \\
\hline T. gemmifera (Fee) Alston & Not yet studied & $n=41(86)$ & Studied (89) \\
\hline T. griffithii (Baker) C. Chr. & Not yet studied & $n=40(90)$ & Not yet studied \\
\hline T. herpetocaulos Holttum & Not yet studied & Not yet studied & Not yet studied \\
\hline T. heterocarpa (Baker) Ching, & Not yet studied & Not yet studied & Not yet studied \\
\hline T. impressa (Fee) Holtum & Not yet studied & $n=78(90)$ & Studied (87) \\
\hline T. ingens (Desv.) C.Chr. & Not yet studied & Not yet studied & Not yet studied \\
\hline T. kehdingiana (Kuhn) M.G. Price & Not yet studied & Not yet studied & Not yet studied \\
\hline T. melanocaulos (Blume) Copel. & Not yet studied & Not yet studied & Not yet studied \\
\hline T. multicaudata (C.B. Clarke) Ching & Not yet studied & Not yet studied & Not yet studied \\
\hline T. paradoxa Sledge & Not yet studied & $n=40 \& 80 \quad(78)$ & Not yet Studied \\
\hline T. polymorpha (Wall, ex Hook.) Copel. & Not yet studied & $\begin{array}{l}n=40,41 \& 80 \\
2 n=80(88)\end{array}$ & Studied (87) \\
\hline $\begin{array}{l}\text { T. pseudosiifolia Fraser-Jenkins \& } \\
\text { Wangdi } \\
\end{array}$ & Not yet studied & Not yet studied & Not yet studied \\
\hline T. puberula C.Chr. & Not yet studied & Not yet studied & Not yet studied \\
\hline T. simonsii (Baker) Ching & Not yet studied & $n=78$ (90) & Not yet studied \\
\hline T. subconfluens Ching & Not yet studied & Not yet studied & Not yet studied \\
\hline T. trimenii C. Chr. & Not yet studied & Not yet studied & Not yet studied \\
\hline T. vasta (Blume) Copel. & Not yet studied & $\mathrm{n}=78$ (90) & Not yet studied \\
\hline T. wightii (C. B. Clarke) Ching & Not yet studied & $n=41 \quad(78,88,86)$ & Studied (89) \\
\hline T. zeilanica (Houttuyn) Sledge & Not yet studied & Not yet studied & Not yet studied \\
\hline
\end{tabular}

Vijaykant and Sathish (85-86) studied cytology of some pteridophytes from Kolli Hills. Recently, Vijaykant et al. (86) studied the cytology of ferns (including T. gemmifera and T. wightii) from Kolli Hills, Eastern Ghats, Tamil Nadu, India.

Amongst the 24 species of Tectaria, cytology of 12 species (half of reported species) were studied (Table 3). There are many species yet to be studied the cytology. The basic chromosome number of genus Tectaria is $40 \& 41$.

\section{Palynological studies}

Palynological studies are taxonomical markers in presuming phylogenetic relationship amongst species. Spores are the essential genetic material for sexual reproduction of vascular cryptogams. In vascular cryptogams, two types of spore are recognized, viz., monolete and trilete. Monolete spores are bilaterally symmetrical (mostly ellipsoidal) with a linear aperture whereas trilete spores are radially symmetrical with a triradiate aperture. The monumental work on spores and pollen morphology was carried out by Erdtman's (91-93). After this publication in palynological studies on different groups of vascular plants increased significantly. Spore morphology of ferns was carried out by Brown (94). Nayar and Devi (87) investigated the spore morphology of twelve species of Tectaria and a single species of Ctenitis. According to them, all spores of Tectariod ferns are monolete, bilateral and perisporate. Rao \& Khare (64) studies the spores of Tectaria amplifolia. An importance of spore study in fern taxonomy 


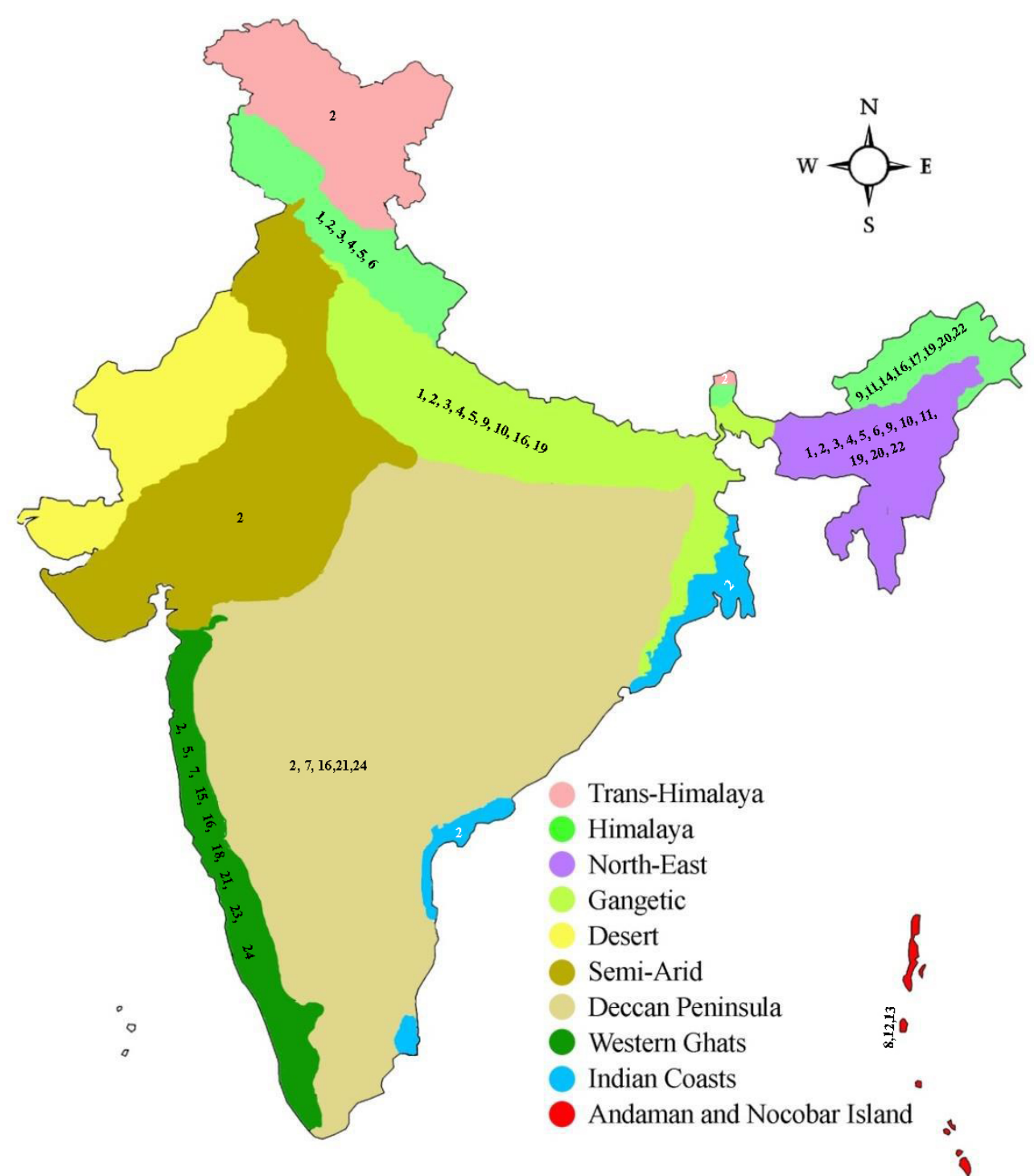

Fig. 2: 1. Tectaria chattagrammica, 2. T. coadunata, 3. T. decurrens, 4. T. fauriei, 5. T. fuscipes, 6. T. griffithii, 7. T. gemmifera, 8. T. herpetocaulos, 9. T. heterocarpa, 10. T. impressa, 11. T. ingens, 12. T. kehdingiana, 13. T. melanocaulos, 14. T. multicaudata, 15. T. paradoxa, 16. T. polymorpha, 17. T. pseudosiifolia, 18. T. puberula, 19. T. simonsii, 20. T. subconfluens, 21. T. trimenii, 22. T. vasta, 23. T. wightii, 24. T. zeilanica

has been stressed by a number of authors and to name Bir (95), Verma (96) Nayar and Devi (87). Devi (97) gave an account of the pteridophytic spores with respect to morphological, aerobiological, environmental and biochemical aspects. The spore of tectaroid ferns through SEM was studied by Holttum $(98,99)$ and concluded that external form of Tectaria spore closely resemble with Ctenitis and Heterogonium. The comparative spore morphology of $T$. coudanata and T. periya was studied by Nayar \& Geevarghese (100). Moy (102) studied the spore-morphology of five species Tectaria and Ctenitis through SEM (Scanning Electronic Microscopy) and TEM (Transmission electron microscopy). According to him (102) Tectaria and Oleandra spores are having a close resemblance with each other. Sharma \& Sharma (103) also studied the spores of Indian species i.e. Tectaria coadunata. Holttum \& Lin (104) studied the spores of Pseudotectaria decaryana using SEM and showed that the later species is different from those of Tectaria while it closely looks similar with Ctenitis and Dryopsis. Tryon and Lugardon (105) studied spores of tectaroid ferns, viz., Tectaria, Ctenitis, Dryopsis, Pteridrys and Pleocnemia using SEM and TEM and provided a detailed idea about the spore ornamentation. Palynology data is very useful for taxonomic purposes at all levels of fern families and below it (106). Chen (107) studied the spore morphology of dryopteridae ferns and observed that the echinulated ornamentation of spores found in Tectaria and Dryopsis were quite different from each other. This result supported that Dryopteridoid ferns are different from Tectarioid ferns. However, Lastreopsis have similar spore ornamentation with genera in Dryoterideae. The characters of the spores suggest that they possess an important phylogenic value at the species level particularly in ornamentation and structure of the perispores (108). Palynology of eleven species of the genus Tectaria Cav. (Tectariaceae-Polypodiaceae) has been carried out (109). According to them, all species are having ellipsoidal, monolete spores and their size ranges in between $25-53 \mu \mathrm{m}$. The biggest spore was observed in T. transiens. Vijayakanth et al. (89) 
studied the palynomorphic studies on the pteridophytes (including the species Tectaria wightii) of Kolli Hills, Eastern Ghats, Tamil Nadu. The spores of all Tectaria species are having different surface patterns, viz., reticulate, granulose, verrucate, psilate, rugulate, cristate, echinate, tuberculate with different shapes such as tetrahedral, globose, ellipsoidal and spherical.

Amongst the 24 species of Tectaria, spore morphology (SEM) of 06 species were studied (Table 3). There are many species yet to be studied the spore morphology.

\section{Molecular studies}

Recent molecular studies assimilating Tectaria have significantly enhanced our knowledge of its limitation and phylogeny. Plastid data have supported the inclusion of Cionidium, Ctenitopsis, Dictyoxiphium, Fadyenia, Hemigramma, Heterogonium, Podopeltis, Psomiocarpa, Quercifilix, and Stenosemia in Tectaria (107,110114). Ding et al. (63) have studied the relations within the Tectaria with emphasizes on the OldWorld species. They used plastid data of 76 accessions of ca. 53 species from China and Philippine (Old World) and 04 accessions representing ca. 04 species from the New World. Subsequently, Zhang et al. (115) analysed both the plastid and nuclear data of 23 accessions representing only 17 species of Tectaria and drawn a phylogeny of Tectariaceae. A Classification of the fern genus Tectaria (Tectariaceae: Polypodiales) based on molecular and morphological evidence is proposed by Zhang and Zhang (116). As far as India is concerned no reports are available on molecular aspects of Indian species.

Barcode of Life Data Systems (BOLD) is a web-based workbench and database supporting the acquisition, storage, analysis, and publication of DNA barcode records. It also has a provision to provide field photographs, herbarium specimen photographs and nucleotide sequence of the plant submitted for comparison of closely related or unidentified plant taxa. DNA barcoding is a method to achieve accurate and rapid species identification by using short and standard DNA regions (117). Hence, there is an urgent need to analyze Indian Tectaria species at molecular level and produce the barcode for each species.

\section{Conclusion}

The review of literature signifies that no much attention is paid on anatomy, cytology, palynology and molecular systematics of Tectaria from the different regions of the World including Indian species of Tectaria. Therefore, there is an urgent need to understand the diversity, taxonomy, anatomy, cytology, palynology and molecular studies on this genus from India as well as the world.

\section{Acknowledgement}

The authors are very grateful to Science and Engineering Research Board (SERB) for providing financial support under NPDF programme.

\section{Competing Interests}

The authors have no conflict of interests.

\section{Authors' contribution}

SMP and RNK collected the specimens from the field and wrote the initial draft of the manuscript, KSR corrected the MS and made grammatical corrections. All the authors approved the final manuscript.

\section{References}

1. Cavanilles AI. Tectaria. Anales Hist. Nat. 1799;1:115.

2. Ding HH, Chao YS, Dong SY. Taxonomic novelties in the fern genus Tectaria (Tectariaceae). Phytotaxa. 2013;122:61-64.

http://dx.doi.org/10.11646/phytotaxa.162.2.5

3. Tryon RM, Tryon AF. Ferns and Allied Plants with Special Reference to Tropical America. 1982;440-481. Springer Verlag N Y Heidelberg Berlin. https://doi.org/10.1111/j.1756-1051.1984.tb02046.x

4. Kramer KU, Green PS. Pteridophytes and Gymnosperms Vol. 1. The families and Genera of Vascular Plants. 1990;104-125. $\quad 2^{\text {nd }}$ Ed. Spinger N Y. https://doi.org/10.1007/978-3-662-02604-5 1

5. Holttum RE. New taxa in the Tectaria group (Polypodiaceae) From Malesia. Blumea. 1991;35:547557.

6. PPG-I. A community-derived classification for extant lycophytes and ferns Journal of Systematics and Evolution. https://doi.org/10.1111/jse.12229

7. Swartz OP. Genera et species filicum ordine systematico redactarum. Jour. Bot. (Schrader). 1801;2:1-120.

8. Smith J. Arrangement and definition of the genera of ferns, with observations on the affinities of each genus Hooker. Jour. Bot. 1841;4:147-198.

9. Presl C. Tentamen Pteridographiae. Theophilus Haase, Prague. 1836.

10. Hooker WJ, Baker JG. Synopsis Filicum. 1874. R Hardwicke London.

11. Beddome RH. Handbook to the ferns of British India, Ceylon and Malay Peninsula. 1883. Thacker Spink \& Co., Calcutta. https://doi.org/10.5962/bhl.title.101756

12. Beddome RH. Supplements to the ferns of British India, Ceylon and Malay Peninsula. 1892. Thacker Spink \& Co., Calcutta. https://doi.org/10.5962/bhl.title.49551

13. Christensen C. Index Filicum. 1905;1-2:1-742. Apud H Hagerup Hafniae.

14. Copeland EB. A revision of Tectaria with special regard to the Philippine species. Philippine Journal of Science. 1907;2:409-418.

15. Christensen C. Index Filicum Supplementum Preliminaire. 1913;1:1-384. Apud H Hagerup Hafniae.

16. Christensen C. A monograph of the genus Dryopteris Part 2. 1920;6:I-I 32. K danske Vidensk Selsk (Ser.8).

17. Blatter E, d'Almeida JF. The Ferns of Bombay. 1922. D B Taraporevala and Sons \& Co, Bombay. https://doi.org/10.5962/bhl.title.55679 
18. Ching RC. The studies of Chinese ferns VII A revision of the genus Tectaria from China and Sikkim-Himalaya. Sinensia. 1931;2:9-36.

19. Christensen C. Filicinae in F Verdoorn (Ed) Manual of Pteridology. 1938;522-550. The Hague:Martinus \& Nijhoff. https://doi.org/10.1007/978-94-017-6111-6 20

20. Ching RC. On the natural classification of the family Polypodiaceae. Sunyatsenia. 1940;5:201-268.

21. Holttum RE. A Revised Classification of Leptosporangiate Ferns. Bot. Jour. Linn. Soc. 1947;53:123-158. $\quad$ https://doi.org/10.1111/j.10958339.1947.tb02554.x

22. Copeland EB. Genera Filicum:The genera of Ferns. 1947. Cronica Botanica, Waltham Mass. U.S.A

23. Holttum RE. The Fern Genus Arcypteris underwood, Reinwardtia, Harbarium Bogoriense. Keb. Raya Indo. 1951;1(2):191-196.

24. Pichi-Sermolli REG. Index Filicum. Supplementum Quartum pro annis I, 1965;934-1960. Utrecht: International Bureae for Plant Taxonomy and Nomenclature.

25. Nayar BK. A phylogenetic classification of the homosporous ferns. Taxon. 1970;19:229-236. https://doi.org/10.2307/1217958

26. Mathew KM. Pteridophytes from the Darjeeling District. Bull. Bot. Soc. Bengal. 1971;25 (1\&2):97-102.

27. Sledge WA. The Tectaroid Ferns of Ceylon. Kew Bull. 1972;27:407-424. https://doi.org/10.2307/4114354

28. Pichi-Sermolli REG. Tentamen Pteridophytorum genera in Taxonomicum ordinem redigendi. Webbia. 1977;31:313-512. https://doi.org/10.1080/00837792.1977.10670077

29. Holttum RE. The Fern Genera Tectaria, Heterogonium \& Ctenitis in the Mascarene Islands. Kew Bull. 1983;38:107-130. https://doi.org/10.2307/4107974

30. Holttum RE. Four Limestone Ferns Assigned to the Genus Tectaria. Indian Fern J. 1984;1:31-39.

31. Dixit RD, Vohra JN. A Dictionary of the Pteridophytes of India. 1984. BSI, Howrah.

32. Holttum RE. Studies in the Fern Genera allied to Tectaria Cav. IV The Genus Ctenitis in Asia, Malesia and the Western Pacific. Blumea. 1985;31:1-38.

33. Panigrahi G. Tectariaceae fam. nov. to replace Aspidiaceae, Frank, nom. illeg. (Pteridophyta). Jour. Orissa Bot. Soc. 1986;8:41-42.

34. Pande PC. A Census of Kumaun Ferns. Indian Fern J. 1990;7:187.

35. Holttum RE. New taxa in the Tectaria group (Polypodiaceae) From Malesia. Blumea. 1991;35:547557.

36. Khullar SP. An illustrated fern flora of Western Himalaya. 1994. International book distributors Dehradun.

37. Kato M, Imaichi R. A broad-laeved variant of the fern rheophyte, Tectaria lobbi. Inter. Jour. Plant Sci. 1992;153(2):212-216. https://doi.org/10.1086/297024

38. Manickam VS, Irudayaraj V. Pteridophytes Flora West Ghats. 1992;256-260. Today \& Tomorrow Printers \& Publishers, New Delhi.

39. Irudayaraj V, Bir SS. Details about some Pteridophytes from the Western Ghats of Goa (India). Indian Fern J. 1997;14:114.

40. Rajagopal PK, Bhat KG. Pteridophytic flora of Karnatak State, India. Indian Fern J. 1998;15:21.

41. Bidin AA, Jaman R. The Pteridophytes of Tawan Hilla Park, Sabah. 1999. ASEAN Review of Biodiversity and Environmental Conservation (ARBEC).
42. Jaman R, Mat-Sallaeh K, Latiff A. Provisional Account and Checklist of Fems and Fem-allies in Bario. 1999 Kelabit Highlands, Sarawak.

43. Chandra S. The Ferns of India. 2000;231pp. International Book Distributors, Dehra Dun.

44. Rojas AF. Eight New species and new ranges of Tectariaceae (Filicales) in the Neotropics. Revi. de biol. Trop. 2001;49 (2):467-87.

45. Shi-Yong D, Xian-Chun Z. Notes on the Fern family Tectariaceae from Hainan Island, China. Acta Phytotax. Sin. 2004;42 (4):375-379.

46. Smith AR, Pryer KM, Schuettpelz E, Korall P, Schneider $\mathrm{H}$, Wolf PG. A classification for extant ferns. Taxon. 2006;55:705-731. https://doi.org/10.2307/25065646

47. Fraser-Jenkins CR. Taxonomic Revision of Three Hundred Indian Subcontinental Pteridophytes With a Revised Census-List. 2008;685pp. Bishen Singh Mahendra Pal Singh, Dehradun.

48. Patil SM, Yadav SR, Dongare MM. Tectaria fuscipes (Wall. ex Bedd.) C. Chr. (Tectariaceae, Pteridophyta), a New Record for Southern India. J. Jap. Botany. 2014;89:187-190.

49. Antony R, Fraser-Jenkins CR, Mohanan NN, Koshy CP. Tectaria puberula (Desv.) C. Chr (Dryopteridaceae: Pteridophyta), a new record for Asia. Indian Fern J. 2014;31:139-142.

50. Dong SY. Correction to the misapplication of the name Tectaria subsageniacea (Tectariaceae) in China. Phytotaxa. 2017;313 (2):217-221. http://dx.doi.org/10.11646/phytotaxa.313.2.8

51. Guang-Da Tang, Li-Bing Zhang. Tectaria moranii (Tectariaceae), a new fern species from Costa Rica, Phytotaxa. 2017;357 http://dx.doi.org/10.11646/phytotaxa.357.3.9

52. Fraser-Jenkins CR, Gandhi KN, Kholia BS. An Annotated Checklist of Indian Pteridophytes Part-II (Woodsiaceae to Dryopteridaceae). 2018;562. Bishen Singh Mahendra Pal Singh, Dehradun.

53. Singh S and Panigrahi G. Fern and Fern allies of Arunachal Pradesh, 1:211. 2005. Bishen Singh Mahendra Pal Singh, Dehradun.

54. Kholia BS. Ferns and Fern-allies of Sikkim: A Pictorial Handbook Part-I. 2010. BSI.

55. Bower FO. The Ferns Vol 1. 1923. Oxford: Cambridge University Press

56. Rao AK, Khare P. Contribution to our knowledge of the sporophyte of Tectaria amplifolia (Alderw) Cristensen. Proceed. Ind. Acad. Sci. 1964;598:328-339.

57. White RA. Comparative Anatomy of The Aspidiaceae: Stelar pattern development in young sporophyte of Tectaria. Amer. J. Bot. 1970;57 (4):458-467. https://doi.org/10.1002/j.1537-2197.1970.tb09837.x

58. Chandra S, Kaur S. Contribution to the morphology of Tectaria: Vascular Organization of the rhizome, Phytomorphology. 1976;26(I):144-150.

59. Salgado AE. Venation Pattern in Philippine Tectarioid Ferns. 1982. Monograph Series No.3. De la Salle University Manila.

60. Salgado AE, Valera NV. A Morpho-anatomical Study of Tectaria grandifolia (Presl) Copeland. Philipp. J. Sci. 1987;116 (4):377-390.

61. Mittal TC, BIR SS. The Indian Substitute of Male Fern (Dryopteris filix-mas (L.) Schott.)- II Drug Macroscopy. Indian Fern J. 2007;24:1-53.

62. Jadhav BV. Taxonomical and Phytochemical studies of Some Pteridophytes of Koyna Wildlife Sanctuary and Its adjoining area. 2011. A PhD. thesis submitted to Shivaji University, Kolhapur. 
63. Ding HH, Chao YS, Callado JR, Dong SY. Phylogeny and character evolution of the fern genus Tectaria (Tectariaceae) in the Old World inferred from chloroplast DNA sequences. Mole. Phylog. Evol. 2014;80:66-78. http://10.3897/phytokeys.78.12040

64. Manton I. Problems of cytology and Evolution in the Pteridophyta. 1950. Cambridge University Press. https://doi.org/10.5962/bhl.title.4667

65. Mehra PN, Verma SC. Cytotaxonomic observations on some West Himalayan Pteridaceae. Caryologia. 1960;13:619-650. https://doi.org/10.1080/00087114.1960.10797101

66. Verma SC, Loyal DS. Chromosome counts in some ferns from Nainital. Curr. Sci. 1960;29:69-70.

67. Verma SC. Variation and evolution in Onychium. Proceed. Ind. Sci. Cong. (Roorkee), Part IV. 1961. 48:9092.

68. Verma SC, Khullar SP. Cytogenetics of the Western Himalayan Pteris cretica complex. Ann. Bot. 1965;29(4):673-681. https://doi.org/10.1093/oxfordjournals.aob.a083980

69. Tindale MD. A monograph of the genus Lastreopsis Ching. Contributions New South Wales National Herbarium. 1965;3:249-339.

70. Morton CV. The genera, subgenera, and sections of the Hymenophyllaceae. Controbution United State National Herbarium. 1968;38(5):153-214.

71. Bir SS. Cytology of Indian pteridophytes, In: Nair PKK, Grover RK \& Verghese TM (Eds) Glimpses. Pl. Res. 1973;1:28-119.

72. Lovis JD. Evolutionary patterns and processes in ferns. Advances Bot. Res. 1978;4:229-415. https://doi.org/10.1016/S0065-2296(08)60371-7

73. Walker TG. The Experimental Biology of Ferns, In;Dyer A F (ed.), The experimental biology or ferns. 1979. Academic Press, London UK.

74. Wanger WH, Wanger FS. Ployploidy in pteridophytes, In: Lewis W L (ed.), Ployploidy: biological relevance. 1980;199-213. Plenum Press.

75. Bhavanandan KV. Studies on the cytology of South Indian Aspidiaceae. Cytologia. 1981;46:195 - 207. https://doi.org/10.1508/cytologia.46.195

76. Khare PB. A note on the chromosome number of the fern flora of Amarkantak Hills. Central India. Sci Cult. 1980;46:138-139.

77. Khare $\mathrm{P}$, Kaur S. Intraspecific polyploidy in Pteris vittata Linn., Cytologia. 1983;48 (1):21-25 https://doi.org/10.1508/cytologia.48.21

78. Irudayaraj V, Manickam VS. SOCGI plant chromosome number reports. V. J Cytol Genet. 1987;22:156-163.

79. Kato M, Nakato N, Cheng X, Iwatsuki K. Cytotaxonomic study of ferns of Yunnan, southwestern China. Bot. Mag. Tokyo. 1992;105(1):105-124. https://doi.org/10.1007/BF02489407

80. Irudayaraj V, Rajkumar SD, Manickam VS. Studies on intraspecific variation in South India ferns: rediscovery of the rare diploid cytotype of Christella parasitica (Thelypteridaceae: Pteridophyte). Fern Gaz. 1995;15:41-50.

81. Jin-Mei L, De-Zhu L, Ding WU. Chromosome numbers of four genera in the Dryopteridaceae. Acta Phytotax. Sin. 2006;44:516-522. https://doi.org/10.1360/aps050030

82. Bir SS, Verma SC. Chromosome atlas of the Indian pteridophytes. 2010;346. Dehra Dun (India): Bishen Singh Mahendra Pal Singh.

83. Zhao HG, Donga SY. A new hybrid of Tectaria (Tectariaceae) from southern China. Phytotaxa.
2016;266(3):213-218.

http://dx.doi.org/10.11646/phytotaxa.266.3.5

84. Vijayakanth P, Sathish SS. A new cytotype of Asplenium decrescens from Kolli Hills, Tamil Nadu. J. Cytol. Genet. 2016;17:69-71.

85. Vijayakanth P, Sathish SS. Pyrrosia porosa (C. Presl) Hovenkamp - a new diploid cytotype of South India from Kolli Hills of Eastern Ghats, Tamil Nadu, India. Inter. Jour. Pl. Bio. Res. 2017;5:1057-1058.

86. Vijayakanth P, Sathish SS, Dominic RS, Irudayaraj V, Kavitha R, Mazumdar J. Studies on the chromosome numbers of ferns from Kolli Hills, Eastern Ghats, Tamil Nadu, India. Caryologia. 2018;71(4):380-396. https://doi.org/10.1080/00087114.2018.1482151

87. Nayar BK \& Devi S. Spore Morphology of Indian Ferns 1. Aspidiaceae. Grana Palynol. 1964;5:80-120. https://doi.org/10.1080/00173136409429131

88. Sankari AL, Bhavanandan KV. Karyomorphological Studies on three species of Tectaria Cav., Indian Fern J. 1993;10:35-39.

89. Vijayakanth V, Sathish SS, Palani R, Thamizharasi T, Vimala A. Palynomorphic studies on the pteridophytes of Kolli Hills, Eastern Ghats, Tamil Nadu. Biosci. Dis. 2017;8(4):752-761.

90. Bidin AA, Go A. Chromosome base numbers for Tectaria and allied genera in peninsular Malaysia. Nat. Hist. Res. 1995;3(2):115-122.

91. Erdtman G. Pollen morphology and plant taxonomy. IV. Labiatae, Verbanaceae and Avicenniaceae. Svensk Botan Tidskrift. 1945;39:279-285.

92. Erdtman G. Pollen Morphology and Plant Taxonomy. 1952;86-91. Cronica Bot. Co. Waltham, Mass U.S.A.

93. Erdtman G. Pollen and spore Morphology and Plant Taxonomy. 1957. Almquist Wiksells, Uppsala, Sweden.

94. Brown CA. What is the role of spores in fern taxonomy? Amer. Fern Journal. 1960;50:6-14. https://doi.org/10.2307/1545238

95. Bir SS. Role of spore morphology in the taxonomy of family Aspleniaceae. Palynologica Bull., 1966-67;2\&3:311.

96. Verma SC. Contribution of spores to fern taxonomy with particular reference to some Pteridaceous members. Paly. Bull., Lucknow. 1966-67;2-3:17-23.

97. Devi S. Spores of Indian Ferns. 1977. To-day Tomorrow's Printers and Publishers, New Delhi, India.

98. Holttum RE. In Flora Malesiana. 1982. Martinus Nijhoff, Dr. W. Junk Publishers, Hague.

99. Holttum RE. Studies in the Fern-genera allied to Tectaria. A commentary on recent schemes of classification. Fern Gaz. 1984;12(6):313-319.

100. Nayar BK, Geevarghese KK. Four new taxa of ferns from Wynad, South India. Bull. Bot. Surv. Ind. 1986;28(S-14):133-145.

101. Bir SS. Contribution to the spore morphology in the taxonomy of some taxa of ferns. Pollen Spore Res. 1976;2:1-28:92-111.

102. Moy JC. Variations of fern spore ultrastructure as reflections of the evolution. Grana Palyno. 1988;27:3951. https://doi.org/10.1080/00173138809427731

103. Sharma A, Sharma BD. Ferns and Fern Allies of Rajasthan (India): Study of spores, Indian Fern J. 1988;5:116-124.

104. Holttum RE, Lin YX. A reassessment of the fern genus Pseudotectaria, Kew Bull. 1989;45(2):257-263. https://doi.org/10.2307/4115683 
105. Tryon AF, Lugardon B. Spores of Pteridophyta. 1991. 446-450 Spinger Verlag,

N.Y. https://doi.org/10.1007/978-1-4613-8991-0

106. Yea CL, Chen MK, Ho YL. SEM studies on spore in Taiwanese fern genera I. Athyrioids. Taiwania. 2000;45(2):181-200.

107. Chen Nien-Chun. Scanning Electron Microscopic Studies on the Spores of Dryopteridoideae from Taiwan, 2006; etd-0822107-103108.

108. Moran RC, Labiak, PH, Hanks JG, Prado J. The phylogenetic relationship of Tectaria brauniana and Tectaria nicotianifolia, and the recognition of Hypoderris (Tectariaceae). Syst. Bot. 2014;39:384-395. https://doi.org/10.1600/036364414x680933

109. Velazquez E, Pacheco L, Mancera G, \& Morales A. Palynology of Eleven Species of the Genus Tectaria Cav. (Tectariaceae-Polypodiaceae). Microsc. and Microana. 2016;22(S3):s1046-1047. https://doi.org/10.1017/S143192761600607

110. Schuettpelz E, Pryer KM. Fern phylogeny inferred from 400 leptosporangiate species and three plastid genes. Taxon. 2007;56, 1037-1050. https://doi.org/10.2307/25065903

111. Liu HM., Zhang XC, Wang W, Zeng H. Molecular phylogeny of the endemic fern genera Cyrtomidictyum and Cyrtogonellum (Dryopteridaceae) from East Asia. Organ. Divers. Evol. 2010;10:57-68. https://doi.org/10.1007/s13127-010-0010-6

112. Liu, HM, Jiang RH, Guo J, Hovenkamp P, Perrie LR., Shepherd L, Hennequin S, Schneider H. Towards a phylogenetic classification of the climbing fern genus Arthropteris. Taxon. 2013;62:688-700. http://www.jstor.org/stable/10.1086/521710
113. Liu HM, HE LJ. Schneider H. Towards the natural classification of tectarioid ferns: Confirming the phylogenetic relationships of Pleocnemia and Pteridrys (eupolypods I). J. Syst. Evol. 2014;161-174. https://doi.org/10.1111/jse.12073

114. Wang FG, Barratt S, Falcon W., Fay MF, Lehtonen S, Tuomisto F, Xing FW, Christenhusz MJ. On the monophyly of subfamily Tectarioideae (Polypodiaceae) and the phylogenetic placement of some associated fern genera. Phytotaxa. 2014;64(1):001-016. http://dx.doi.org/10.11646/phytotaxa.164.1.1

115. Zhang L, Zhou XM, Chen De-K, Schuettpelz E, Knapp R, Ngan TL, Luong TT, Dang MT, Duan YF, Hai HE, Gao XF, Zhang LB. Global phylogeny of the fern genus Tectaria (Tectariaceae: Polypodiales) based on plastid and nuclear markers identifies major evolutionary lineages and suggests repeated evolution of free venation from anastomosing venation. Molec. Phylogen. Evol. 2017;114 295-333. http://dx.doi.org/10.1016/j.ympev.2017.05.020

116. Zhang L, Zhang LB. A Classification of the Fern Genus Tectaria (Tectariaceae: Polypodiales) Based on Molecular and Morphological Evidence. Ann. Missouri Bot. Gard. 2018;103(2):188-199. https://doi.org/10.3417/2017007

117. Hebert, P.D., A. Cywinska and S.L. Ball. Biological identifications through DNA barcodes. Proc. R. Soc. Lond. B Biol. Sci. 2003;270:313-321. https://doi.org/10.1098/rspb.2002.2218

118. Patil SM. Systematic Studies on the pteridophytes of Satara District (Maharashtra). A Ph.D. thesis submitted to Shivaji University, Kolhapur. 